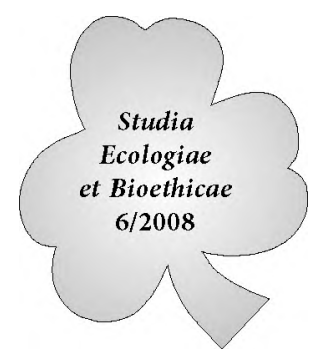

\title{
Z prac Wydziału Filozofii Chrześcijańskiej Pierwszy w Europie „Kodeks Etyki Diagnosty Laboratoryjnego"
}

Wobec niezwykłego postępu w naukach medycznych, dających ogromne możliwości głębokiej ingerencji w procesy zachodzące w ludzkim organizmie na naszych oczach dokonuje się prawdziwa rewolucja w dziedzinach dotyczących ochrony zdrowia i życia człowieka. Sama zaś medycyna coraz częściej kojarzona jest bardziej z nowoczesnym sprzętem, niż z relacją lekarz - pacjent. Na dodatek wraz z poszerzającymi się możliwościami diagnostycznymi i terapeutycznymi medycyna wchodzi do naszego codziennego życia osobistego, rodzinnego i zawodowego. Jednym słowem, jesteśmy świadkami postępującego procesu medykalizacji życia na każdym jego etapie. Prokreacja, narodziny, życie, choroba, śmierć - wszystko to ma dziś wymiar głęboko medyczny. Rodzimy się w szpitalu, leczymy się w szpitalu, poprawiamy nasz wygląd w szpitalu. W szpitalu coraz częściej dochodzi do sztucznej prokreacji i do medycznie kontrolowanej śmierci.

Wraz ze wzrostem możliwości diagnostycznych i terapeutycznych pojawiają się nowe, dotąd nieznane zagrożenia ze strony wysoko rozwiniętych technologii biomedycznych, co sprawia, że raz po raz medycyna staje się przedmiotem wielkich debat etycznych, które są okazją do interdyscyplinarnej refleksji nad zagrożeniami człowieka we współczesnym świecie. Wyrosła z filozofii medycyna wraz z naukami przyrodniczymi zatoczyła ogromny krąg i na nowo wraca do źródeł szukając w filozofii i religii uzasadnień dla swych działań. Stanowi to nowe wyzwanie zarówno dla nauk, jak i filozofii.

Już na przełomie dziewiętnastego i dwudziestego wieku, przy okazji wielkich światowych wystaw techniki pytano $\mathrm{z}$ niepokojem ${ }^{1}$ czy rozwojowi możli-

Jednym z motywów zwołania Pierwszego Międzynarodowego Kongresu Filozoficznego, który odbył się przy okazji Swiatowej Wystawy \echniki w 1900 roku w Paryżu było zrównanie dysproporcji między gwałtownie rozwijającymi się naukami technicznymi i filozofią. Organizator Kongresu Xavié Léon przypomniał przy tej okazji wystąpienie Renana na podczas Pierwszej Wystawy Światowej, w którym z niepokojem przestrzegał przed niebezpieczeństwem materializmu płynącego z zachwytu dla techniki. „Le Moment 1900 en philosophie”, Etudes réunies sous la direction de Frédéric Worms, Presses Universitaires du Septentrion, 2004. 
wości technicznych towarzyszy w wystarczającym stopniu refleksja moralna. Czy coraz bardziej perfekcyjne narzędzia, które mają służyć człowiekowi nie staną się dla niego źródłem zagrożeń? Pytania te stają się coraz bardziej aktualne zwłaszcza wobec ewolucji samego rozumienia medycyny i jej zadań. Oto bowiem dla przykładu ze zdumieniem obserwujemy jak w relację lekarz - pacjent wchodzi ze swoimi skomplikowanymi instrumentami technika. Dotyczy to zwłaszcza diagnostyki, która oparta jest na najnowocześniejszych technologiach biomedycznych. Otwiera ona perspektywę nowych, dotąd nieosiągalnych możliwości terapeutycznych. Wysoko wyspecjalizowana diagnostyka, daje podstawy do budowania nowej wizji nowoczesnej medycyny, gdyż jej możliwości nie tylko pozwalają na stawianie trafnych diagnoz i dobór odpowiednich, skutecznych działań terapeutycznych, ale przede wszystkim pozwalają one działać prewencyjnie.

Mając świadomość wagi jaką we współczesnej medycynie odgrywają nowoczesne badania laboratoryjne, polscy diagności jako jedni z pierwszych w Europie stworzyli nową korporację zawodową zorganizowaną w strukturze Krajowej Izby Diagnostów Laboratoryjnych. Do wielu zawodów zaufania publicznego doszedł jeszcze zawód diagnosty z całym bagażem skutków odpowiedzialności zawodowej. Już u samych początków tworzenia się tej nowej korporacji zauważono, że jednym z podstawowych narzędzi formacji zawodowej winna być oparta na trwałych fundamentach moralnych etyka, która nie ograniczy się do stworzenia mniej lub bardziej satysfakcjonujących zakazów i nakazów. Organizatorzy struktur korporacyjnych słusznie zauważyli, że formacji zawodowej nie da się oprzeć wyłącznie na poziomie rozwiązań legislacyjnych, prawnych - choć dobre prawo może odgrywać również rolę formacyjną.

Kilka lat temu prezes Krajowej Izby Diagnostów Laboratoryjnych dr Henryk Owczarek zwrócił sie do mnie z prośbą o przygotowanie opartego na założeniach etycznych klasycznej tradycji hipokratejskiej „Kodeksu etyki laboratoryjnej". Przygotowany Kodeks miał być skonsultowany z członkami Komisji Etyki, Komisji Odpowiedzialności Zawodowej i ostatecznie przedstawiony do zatwierdzenia Krajowemu Zjazdowi Diagnostów Laboratoryjnych.

\ak zaczęła się moja filozoficzna przygoda $\mathrm{z}$ nową korporacją zawodową a tym samym $z$ nowym zespołem zagadnień moralnych i filozoficznych. Ponieważ, jak to już zaznaczono, nie chodziło tylko o przygotowanie zgrabnego w swych sformułowaniach, poprawnego z punktu widzenia etyki tekstu Kodeksu, ale także o przekonanie do zawartych w nim rozwiązań środowiska diagnostów. Praca nad tym dokumentem wymagała długiego dialogu interdyscyplinarnego z przedstawicielami wielu dziedzin. Nie chodziło bowiem tylko o dobry tekst, lecz o tekst, który będzie zaakceptowany przez przedstawicieli korporacji. Mając za sobą udział w niegdyśs toczonych w środowisku lekarskim przy okazji wprowadzania „Kodeksu etyki lekarskiej” długie, pełne nieporozumień i uprzedzeń 
debaty, wiedziałem, że czeka mnie trudna praca. Z pokorą słuchałem racji praktycznych i teoretycznych prawników i przyrodników. Nasza kilkuletnia praca ostatecznie zakończyła się przygotowaniem „Kodeksu diagnostów laboratoryjnych" który został przyjęty na Krajowym Zjeździe stając się pierwszym oficjalnym dokumentem tego typu w Europie ${ }^{2}$.

\section{Kodeks etyki, bioetyki czy deontologii?}

Rzeczą zupełnie zrozumiałą jest pojawienie się pytania czy proponowany kodeks postępowania w zawodach medycznych, w tym, określający normy postępowania diagnosty laboratoryjnego winien być kodeksem etycznym, bioetycznym, czy wreszcie kodeksem deontologicznym? Wbrew pozorom nie jest to spór o pojęcia. Wystarczy prześledzić historię etyki lekarskiej na przestrzeni ostatniego stulecia, by zobaczyć ciekawą ewolucję, którą można by określić swoistego rodzaju ucieczką od etyki.

Kiedy rozpoczynałem swoje zajęcia w warszawskiej Akademii Medycznej pojawiły się sugestie, iż po latach jedynie słusznej ideologii marksistowskiej, która zastępowała wszelkiego rodzaju refleksję humanistyczną, nie należy używać pojęcia etyki, gdyż jest przestarzałe i ma zabarwienie religijne. Jeden z profesorów ze szczerej troski o obecność nauczania etyki w szkołach medycznych sugerował, by zastąpić je pojęciem deontologii, gdyż jest ono bliższe prawu i brzmi bardziej naukowo. Pozostali najchętniej widzieliby na akademii medycznej wykłady z bioetyki. Przecież jeśli dziś tak dużo mówi się o problemach moralnych związanych z ludzkim życiem, to właśnie dzięki bioetyce. Można by nad tym przejść do porządku dziennego, uznając zamianę pojęcia etyka na bardziej modne pojęcie bioetyki, gdyby ta zamiana nie powodowała żadnych skutków w naszej świadomości. Jeśli jednak w kulturze, w której istnieje kilka tysięcy lat tradycji refleksji moralnej pojawił się moment, w którym wolimy pojęcie etyki zastępować pojęciem deontologii, czy bioetyki, musi istnieć ku temu jakiś powód. Jak pisze Marc Andronikof, „...pojęcie bioetyki wprowadzone do języka przez Amerykanów znaczy tyle, co etyka związana z naukami dotyczącymi życia. Øymczasem wyodrębnienie tej dziedziny z etyki, w gruncie rzeczy pozbawia bioetykę wymiaru etyki wiążąc ją bardziej z biologią, niż egzystencją ludzką. Na taką bioetykę zgodzić się nie możemy. Nie ma żadnej bioetyki oderwanej od etyki."

2 Jedynym dokumentem, który wyznaczał dotychczas normy postępowania w ramach wykonywania zawodu była „Konwencja o Ochronie Praw Człowieka i Godności Istoty Ludzkiej wobec Zastosowań Biologii i Medycyny"

3 Marc Andronikof: Transplantation d'organes et ethique chretienne, Les Editions de l'Ancre, Suresnes 1993, s 103. 
Jeszcze bardziej radykalnie ocenia nową naukę prof. Roberto Andorno z Uniwersytetu w Buenos Aires, który identyfikując źródła nowej nauki pisze, iż w świecie anglosaskim pojęcie „bioetyka” jest używane w znaczeniu dosyć ideologicznym, ukazując bioetykę jako naukę, która - nawet jeśli nikt tego nie mówi wprost - ma za swój punkt wyjścia samą biotechnologię i jej wymagania. Pierwsza w tym wypadku w bioetyce jest praktyka, a moralne jej uzasadnienia są drugoplanowe. $W$ ten sposób bioetyka nie jest autonomiczną nauką, ale wprost pewnym narzędziem ideologicznym ${ }^{4}$ uzasadniania praktyki post factum. W gruncie rzeczy tak rozumiana bioetyka nie jest etyką, ani też nie jest nauką. ${ }^{5}$

Co prawda w polskiej literaturze bioetyka rozumiana jest jako jedna $z$ etyk szczegółowych traktujących o problemach związanych z ludzkim życiem, to jednak nie znajduję uzasadnienia, by rezygnować z klasycznego pojęcia, za którym stoi wielowiekowa tradycja. Kodeks, który ma być narzędziem zawodowej formacji osób powołanych do służby ludzkiemu życiu powinien być mocno oparty na etyce zakorzenionej w personalistycznej antropologii. Jako zespół norm określających godziwość działań, kodeks ma wymiar deontologiczny. Jednak deontologia, jako nauka o zakazach i nakazach moralnych sama domaga się uzasadnienia proponowanych norm. Sama deontologia nie wystarczy. Jest za uboga dla człowieka, który dzięki swym naturalnym władzom poznawczo-wolitywnym zdolny jest do poznania, oceny i wyboru dobra dla siebie. Deontologia ogranicza człowieka, etyka ucząc wyborów zgodnych z prawdą i dobrem pozostawia człowiekowi wolność zarazem wskazując normy i wartości, które są swoistego rodzaju drogowskazami godziwego życia. Dlatego Kodeks diagnostów laboratoryjnych jest kodeksem etycznym.

\section{Źródła}

Refleksja moralna nad zagadnieniami związanymi z wykonywaniem zawodów medycznych sięga daleko w przeszłość aż do czasów Hipokratesa ${ }^{6}$, który

4 Co prawda można znaleźć autorów, którzy nie widzą możliwości uprawiania etyki uważając wszelką refleksję tylko za jakąś postać ideologii. Porównaj dla przykładu pogląd szwajcarskiego filozofa Gonsetha, który pisze: „W żadnej sytuacji, człowiek nie ma możliwości formułowania absolutnych sądów. Każda informacja, każde spostrzeżenie, każda decyzja nie może być sformulowana bez odniesienia do jakiejś ideologii. W takim razie nie istnieje żadna moralność poza związkiem z jakąś ideologią.” Ferdinand Gonseth: „Science, morale et foi”, Lausanne, 1986, s 131.

5 Roberto Andorno, prof.de la faculté du droit de l'Université Austral, Buenos Aires: „La bioéthique", Paris 1997. s 6 .

6 Hipokrates (460-370 przed Chr.) urodził się w rodzinie lekarskiej Asklepiadów. Żyl w okresie największego rozkwitu filozofii greckiej. Był to także czas rozkwitu matematyki oraz medycyny. Hipokrates założył swoją szkołę medyczną, którą rozwijał m.in. ze swoimi synami Drakonem i Thessalosem oraz zięciem Polibosem. Por. 囚. Biesaga: Przysięga Hipokratesa, Medycyna Praktyczna 200r nr 7-8 s. 23. 
pozostawił nam pierwszy spisany kodeks moralny znany pod nazwą „Przysięgi Hipokratesa”. By docenić wartość tego niezwykłego dokumentu, wystarczy uświadomić sobie, że Hipokrates żył kilkaset lat przed naszą erą a jak sądzą niektórzy sam tekst przysięgi powstał kilka tysięcy lat wcześniej.7 Wiemy jednak doskonale, że wspomniana przysięga była przez całe wieki drogowskazem dla tych, którym ludzie powtarzali swoje zdrowie, a nawet swoje życie. Aż do niedawna każdy absolwent studiów medycznych wchodząc do zawodu składał właśnie „Przysięgę Hipokratesa". Niestety dziś pozostała tylko tradycyjna nazwa przysięgi, podczas gdy teksty przyrzeczeń proponowane przez akademie medyczne zarówno w Polsce, jak i na świecie mają niewiele wspólnego z oryginałem. Najwspanialsza tradycja naszej cywilizacji niemalże na naszych oczach została załamana. Przysiędze zarzuca się, że jest przestarzała i dziś należy szukać nowych rozwiązań, nowych wzorów postępowania w obrębie zawodów medycznych. Opinie te opierają się na nieporozumieniu wynikającym ze złego rozumienia norm moralnych, które pozostając wzorami godziwych zachowań wobec siebie i drugiego człowieka są niezmienne, mimo zmieniających się warunków życia, rozwijającej się techniki i zmian cywilizacyjnych. Norma moralna, która mówi „nie zabijaj” była tak samo aktualna wówczas, gdy zabójstwo mogło być dokonane przy pomocy zwykłego kamienia czy kija, jak i dziś, gdy człowiek stosuje bardziej skuteczne metody przy pomocy wyspecjalizowanej broni opartej na najnowszych technologiach, czy stosując „humanitarne” zabiegi eutanazji.

\section{Czlowiek}

Normy moralne zapisane w tekście „Przysięgi Hipokratesa” są niezmienne, gdyż niezmienna jest natura człowieka. Niezmienne są też wartości, których obrona jest obroną człowieka. Zawsze bowiem podstawową wartością, a więc tym co najcenniejsze w człowieku i co wymaga naszej uwagi i troski jest nasze życie. Życie jest podstawową wartością, gdyż na nim opiera się to wszystko, czym jesteśmy. Na niej opierają się inne wartości. Bezpośrednio z życiem związane jest zdrowie, które oznacza nic innego, jak prawidłowe funkcjonowanie naszego organizmu. Brak zdrowia utrudnia realizację innych wartości, utrudnia rozwój naszego życia osobowego, a czasem prowadzić może do utraty życia. Dlatego w etyce diagnosty laboratoryjnego, podobnie jak w etyce innych zawodów medycznych podstawową i niezmienną normą moralną jest chronić życie i zdrowie człowieka.

„Współczesne badania dokonane przez Naguibe Rida (1955) ustalają, że przysięga przypisywana Hipokratesowi jest znacznie starsza i pochodzi z Egiptu. Powstała ona prawdopodobnie 3000 lat p.n.e. Por. Refleksje nad etyka lekarskq pr. zbr pod red prof. Krystyny Osińskiej, Warszawa 1992 s. 9. 
Na pytanie o definicję etyki odpowiadamy zazwyczaj, że jest ona nauką, w której wypracowuje się normy chronienia osób w oparciu o rozpoznanie prawdy o czlowieku. W etyce określamy, co jest dobre dla człowieka, co służy jego osobie a co człowiekowi zagraża, co niszczy jego psychofizyczną, osobową strukturę. Jeśli mówimy, że normy moralne znajdują swoje uzasadnienie w prawdzie o człowieku, etyka zawsze będzie na miarę antropologii, czyli filozofii człowieka. Jeśli bowiem przyjmiemy materialistyczną, czy biologiczną koncepcję człowieka, co prawda można będzie w oparciu o nią zbudować i uzasadnić normy chroniące zdrowie i życie na poziomie tym, którym zajmuje się dziś ekologia ${ }^{8}$, czyli nauka o ochronie naturalnego środowiska człowieka, ale na tym poziomie takie wartości jak szczęście, wolność czy godność człowieka nie znajdują uzasadnienia. Dlatego nie można redukować rozumienia człowieka do poziomu struktury biologicznej, czy materialnej. Jeśli chcemy budować etykę na miarę prawdy o człowieku, musimy ją oprzeć na personalistycznej koncepcji człowieka. Bo człowiek przede wszystkim jest osobą i realizuje się w życiu osobowym. ${ }^{9}$ Człowiek chce być zdrowy, chce żyć, ale jego wymiar daleko przekracza poziom życia biologicznego. Człowiek bowiem chce poznawać, rozwijać się w sposób wolny, chce rozumieć swoje miejsce na ziemi, chce wreszcie realizować siebie w odniesieniu do innych poprzez miłość, przyjaźń, zaufanie, powołanie i służbę. Đo są pojęcia, które opisują prawdziwą rzeczywistość człowieka. Bez nich norma mówiąca o ochronie wartości, którą nazywamy godnością człowieka ${ }^{10}$ staje się niezrozumiałym pustym postulatem.

\section{Prawo naturalne}

Podstawowe normy moralne, które każdy potrafi rozpoznać rozumem stanowią razem to, co nazywamy prawem naturalnym. ${ }^{11}$ \rudności ze zrozumieniem prawa naturalnego po epoce oświecenia i pozytywizmu wynikają z zaniechania

8 Znany szwajcarski filozof Marie Dominique Philippe zauważa, że pojęcie ekologii, jako ochronie naturalnego środowiska człowieka wymaga doprecyzowania. Czyż naturalnym środowiskiem rozwoju człowieka jest tylko czysta woda i powietrze, czy człowiek nie potrzebuje do rozwoju rodziny, możliwości rozwoju intelektualnego, czyż nie w równym a może nawet większym stopniu zagraża nam nie tylko ocieplenie klimatu ale groźne ideologie niszczące nasze myślenie? Por. Marie Dominique Philippe: „Lettre a un ami. Itinéraire philosophique” Paris 1990 s. 9 i następne.

9 Por. Marie Dominique Philippe: Lettre à un amie, Paris 1990, s. 128.

10 Palazzani Cf. L.: La fundamentacion personalista en bioetica, Cuadernos de bioética nr 14, 1993, s. 48.

11 „Prawo naturalne oznacza na podstawowych imperatywach oparty zbiór norm kategorialnych, obiektywnych i absolutnych (czyli powszechnych i niezmiennych), które uzdalniają podmioty rozumne do spełniania aktów wewnętrznie dobrych, a unikania wewnętrznie złych." Por. Dadeusz ŚLIPKO: Etyka ogólna, Kraków 1984 s. 254. 
poszukiwań filozoficznych na rzecz takich czy innych ideologii. ${ }^{12}$ Jeśli nie umiemy odpowiedzieć na pytanie kim jest człowiek, nie potrafimy także odpowiedzieć na pytanie, jak chronić człowieka. Wtedy w miejsce osoby ludzkiej, jako przedmiotu troski refleksji etycznej pojawić się musi cokolwiek innego, na przykład postęp. \rudno dziś człowiekowi żyjącemu w świecie z dnia na dzień zmieniającej się cywilizacji walczyć z postępem. Zresztą to byłoby nierozsądne. Postęp sam w sobie jest kategorią, której nie można ocenić bez odniesienia do człowieka. Wszystko, co służy człowiekowi jest dobre. Jeśli postęp nie zagraża człowiekowi, jest dobry, jeśli nie - jest czymś zlym. Jeśli kategoria postępu staje się podstawą norm moralnych - człowiek już nie jest chroniony. \aka etyka staje się niebezpieczną ideologią. ${ }^{13} \mathrm{Z}$ wielkim niepokojem mówił to kiedyś francuski filozof Henri Bergson. Ideologie postępu rozwijają techniczne możliwości ludzkiej działalności nie rozwijając refleksji nad sensem i moralnymi skutkami tej działalności. Dziś widać to dosyć wyraźnie w kwestiach związanych z manipulacjami genetycznymi, klonowaniem czy manipulacjami na ludzkim embrionie. Słuchając dyskusji dotyczących problemów moralnych zgłaszanych przez etyków ma się wrażenie, że etyka hamuje postęp. A cóż znaczy postęp, który nie służy człowiekowi, który wprost zwraca cię przeciwko dobru człowieka, który staje się przedmiotem, instrumentem realizacji takich, czy innych pomysłów. Czy taki postęp może być w ogóle wartością?

Jeśli normy moralne mają chronić człowieka, muszą to być normy znajdujące swoje solidne ugruntowanie w prawdzie o człowieku. Prawda gwarantuje powszechność i obiektywność norm moralnych. Nie do przyjęcia są etyki sytuacyjne, etyki relatywistyczne, które mówią, że raz rzeczą dobrą jest chronić życie człowieka, raz nie. \o zależy od kontekstu, od sytuacji. \aka etyka nie chroni człowieka. \aka etyka uzależnia dobro człowieka od okoliczności, sytuacji, które stają się ważniejsze niż człowiek, które decydują o tym czy chronić osobę ludzką, czy nie.

Człowiek zdolny do poznania posiada zarazem zdolność do oceny tego, co poznane. Potrafi zatem uporządkować rzeczywistość według hierarchii wartości. 冈o pomaga nam w życiu codziennym dokonywać wyborów. Mówimy często, że wybierając w życiu różne cele kierujemy się wartościami. ${ }^{14}$ Pewne rzeczy cenimy,

12 Mam tu na myśli nie tylko ideologie polityczne na wzór dialektyki marksistowskiej zdolnej wszystko uzasadnić procesem dziejowym, walką klas, ale także na przykład wszechobecną dziś ideologię postępu.

13 Roberto Andorno, prof.de la faculté du droit de l'Université Austral, Buenos Aires, PUF, Paris 1997 s. 6.

14 „Przez wartości moralne rozumieć będziemy ogólne wzory postępowania (np. Sprawiedliwość, obowiązek, prawdomówność, miłość) odnoszące się do działania ludzkiego i wyrażające doskonałość, która nie tylko odpowiada tym działaniom i w nich się urzeczywistnia, ale urzeczywistniając się w nich doskonali równocześnie człowieka jako osobę,; dzięki temu wzory te stanowią wyłącznie człowiekowi właściwe rodzaje dóbr, stawiane wyżej nad inne dobra, a tym samym cenione." por. \adeusz Ślipko: tamże s. 181. 
pewnych nie. Patrząc na postępowanie człowieka, możemy rozpoznać, jakimi kieruje się wartościami. Wartości zaś nie mogą być arbitralnie ustalane. Podobnie jak normy moralne winny one wynikać z prawdy o człowieku. I tak jak normy moralne winny być niezmienne. Nie możemy powiedzieć, że życie ludzkie jest raz rzeczą cenna, to znaczy jest wartością, raz nie. Jednym z powodów kryzysu we współczesnej etyce jest zrelatywizowanie wartości życia do jakości życia. Coraz częściej słyszy się, ze życie jest wartością wtedy, gdy jest to życie pięknego zdrowego człowieka, natomiast nie jest już wartością w przypadku ludzi kalekich, chorych, czy upośledzonych. Można spotkać się także z relatywizowaniem wartości ludzkiego życia do funkcji społecznych, do roli w rodzinie. Człowiek społecznie użyteczny jest wartością, natomiast człowiek bez zawodu, człowiek chory samotny już taką wartością nie jest.

By zidentyfikować przyczynę takiego stanu rzeczy wystarczyłoby przytoczyć naukę Arystotelesa o kategoriach bytu. Aby być biednym, bogatym, zdrowym, czy chorym - trzeba najpierw być. Najpierw jest człowiek, a później są warunki, które go określają. Jeśli etyka dotyka warunków życia, to nie dla nich samych, ale dla człowieka. A ten zawsze jest taki sam. \emu zawsze przysługuje godność ze względu po prostu na to, że jest człowiekiem, a nie ze względu na to że jest stolarzem, lekarzem, że jest bogaty albo biedny.

„Kodeks etyki diagnosty laboratoryjnego”, który został przyjęty na Zjeździe Krajowej Izby Diagnostów Laboratoryjnych w styczniu 2006 roku stanowi zbiór podstawowych norm moralnych określających działania w zakresie wykonywania zawodu diagnosty laboratoryjnego jako zawodu zaufania publicznego. Jak przystało na kodeks, normy mają charakter ogólny, określają zasady postępowania diagnosty i jako takie stanowią podstawę do ocen działań członków korporacji.

Analizując poszczególne paragrafy kodeksu można zauważyć, że opiera się on na przyjęciu podstawowych wartości moralnych niezbędnych do tego, by wszystkie nasze działania były skierowane na dobro człowieka. Mimo, iż w odróżnieniu od lekarza, który ma bezpośredni kontakt z chorym pacjentem, diagnosta często pozostaje w swoim laboratorium, dysponując tylko materiałem do badania, naczelną wartością, którą kieruje się diagnosta pozostaje dobro pacjenta. Đym dobrem jest zdrowie a często nawet życie człowieka, którego uratowanie zależy od zastosowania podjętej terapii na podstawie postawionej diagnozy w oparciu o rzetelnie wykonane badania diagnostyczne. Rozwój medycyny idzie w kierunku rozwoju diagnostyki. ${ }^{15} \mathrm{Nic}$ więc dziwnego, ze ta dziedzina niesłychanie rozwija się $\mathrm{i}$ że tak wielkie nadzieje z nią wiążemy. Ale wraz z nadziejami stawiamy diagnostyce także wysokie wymagania. Diagnostyka nawet najbardziej technolo-

15 Owszem zawsze pojawia się niepokój, czy to nie stanowi zagrożenia dehumanizacją medycyny, kiedy to lekarzowi nie będzie potrzebny pacjent - wystarczą mu bowiem wyniki wyskakujące z komputera. 
gicznie zaawansowana nie będzie spełniała swojej roli, jeśli nie będzie realizacją podstawowych norm moralnych, które chronią człowieka.

Oprócz życia i zdrowia ludzkiego wartościami moralnymi pozwalającymi realizować zadania diagnosty laboratoryjnego będzie rzetelność, odpowiedzialność, uczciwość, ale także kompetencja i sumienność. Nieocenione w życiu każdego człowieka, a także w zespołach laboratoryjnych są te wartości, które pozwalają owocnie współpracować dla dobra pacjentów, a są nimi życzliwość, wyrozumiałość, przyjaźń, zaufanie wierność wobec złożonych obietnic, bądź przyjętych zobowiązań. Wszystkie te wartości znajdują swoje uzasadnienie w celu naszych działań, którym jest pomoc człowiekowi, który od nas jej potrzebuje. Poza tą naczelną zasadą wymienione wyżej wartości zmieniają swój charakter.

\section{Zaufanie publiczne}

Jeśli już na początku zaznaczyliśmy, że zawód diagnosty ma status zawodu zaufania publicznego, to musimy zauważyć jak bardzo ważne są te wartości, których realizacja przyczynia się do budowania owego etosu zaufania publicznego. Ktoś, komu się ufa, to człowiek solidny, ktoś, kto nie kłamie, kto nie zrezygnuje wobec trudności lub w sytuacji rozpoznania, że moje działania nie przynoszą mi spodziewanych korzyści. Jednym słowem to człowiek kierujący się jasnymi, wyraźnie sprecyzowanymi zasadami moralnymi, którym zawsze pozostanie wierny. Zarazem jest to ktoś, dla kogo wartością nie są tylko własne sukcesy i korzyści, ale kto w poczuciu odpowiedzialności dba o wizerunek reprezentowanej przez siebie korporacji, ఐo ktoś, kto umie się przyznać do porażki i błędu i kto ma odwagę życzliwie zwrócić uwagę, bądź podjąć inną stosowną interwencję w sytuacji nieprawidłowych zachowań swoich kolegów. \o wreszcie ktoś odpowiedzialny. Co to znaczy odpowiedzialność w zawodzie diagnosty laboratoryjnego, odpowiedzialność w życiu. Znany krakowski etyk ks. Prof. Đadeusz Ślipko ${ }^{16}$ wiąże pojęcie odpowiedzialności z poczytalnością i rozumnością. Człowiek odpowiedzialny, to ktoś dojrzały emocjonalnie i osobowo, kto potrafi w pełni świadomie podejmować decyzje w poczuciu pełnego przyjęcia na siebie skutków mojej decyzji. Człowiek odpowiedzialny, to ktoś wewnętrznie silny, kto ma odwagę z pełną świadomością podejmować mądre decyzje i nie uciekać przed trudnościami $w$ ich realizacji ani przed ich następstwami. Jednym słowem, to ktoś, komu się ufa, ktoś, kto nas nie zawiedzie. Czyż nie tego właśnie oczekujemy od personelu medycznego na każdym etapie naszego procesu leczenia, od którego zależy nasze zdrowie i nasza przyszłość?

16 „Odpowiedzialność oznacza znowuż taką właściwość tegoż podmiotu, mocą której dobro lub zło zawarte w treści spełnionego przezeń czynu staje się cząstką składową moralnej treści jego osobowości, wskutek czego ponosi on związane z czynem konsekwencje." por. 冈. Ślipko tamże s. 386 . 


\section{Kodeks Etyki Diagnosty Laboratoryjnego}

Potrzeba ustanowienia Kodeksu Etyki Diagnosty Laboratoryjnego wynika z rozwoju medycyny, w której coraz większą rolę odgrywa wyspecjalizowana diagnostyka laboratoryjna. Pozwala ona nie tylko ustalać trafne diagnozy umożliwiające podejmowanie skutecznych działań terapeutycznych, ale - w coraz większym stopniu - przyczynia się do rozwoju samego lecznictwa i skutecznej profilaktyki medycznej. Jest rzeczą zrozumiałą, że wraz ze wzrostem znaczenia diagnostyki laboratoryjnej w świadomości świadczeniodawców i pacjentów uzyskała ona status zawodu zaufania publicznego.

W praktyce oznacza to, że diagności laboratoryjni stawiają sobie wysokie wymagania moralne i zawodowe. Kodeks Etyki Diagnosty Laboratoryjnego, którego sygnatariuszami są indywidualni diagności laboratoryjni poprzez swoich przedstawicieli zebranych na Nadzwyczajnym Krajowym Zjeździe Diagnostów Laboratoryjnych w dniu 13 stycznia 2006 r., odgrywać będzie ważną rolę w procesie kształcenia specjalistów o wysokim poziomie moralnym i właściwych postawach zawodowych. Kodeks, stanowiąc wyraz ukształtowanej świadomości moralnej środowiska, jest podstawą do oceny zawodowego zaangażowania i postaw moralnych członków korporacji.

Kodeks Etyki Diagnosty Laboratoryjnego opiera się na powszechnie przyjętych normach etyki oraz zasadach wynikających z tradycji zawodu. Naczelną normą postępowania diagnosty laboratoryjnego jest dobro osoby ludzkiej, które winno być chronione zarówno w odniesieniach indywidualnych, jak i społecznych. $Z$ zasady tej wynika powinność poszanowania godności człowieka, jak również budowanie takich odniesień w pracy zawodowej, by jej naczelnym celem byla służba człowiekowi według powszechnie cenionych wartości, takich jak: uczciwość, rzetelność i kompetencja.

\section{ZASADY OGÓLNE:}

$\S 1$

Diagnosta laboratoryjny powinien wykonywać swoje zadania w sposób zgodny z powszechnie przyjętymi normami etycznymi, zasadami sztuki zawodu oraz przepisami prawa regulującymi wykonywanie zawodu.

$\$ 2$

Dobro pacjenta jest dobrem nadrzędnym, wynikającym z jedyności i niepowtarzalności osoby ludzkiej. 
$\$ 3$

Nadrzędne wartości moralne, takie jak: dobro, prawda, wolność, równość, sprawiedliwość dyktują sposób i zasady postępowania wobec pacjenta.

\section{$\$ 4$}

Diagnosta laboratoryjny, postępując według zasad rzetelności, uczciwości, bezstronności i wiarygodności oraz zgodnie z zasadami ekonomiki, powinien wykonywać swoje czynności z szacunkiem dla osoby ludzkiej.

\section{$\$ 5$}

Mając na uwadze doniosłość uprawianego zawodu, diagnosta laboratoryjny podejmuje swoje obowiązki w poczuciu odpowiedzialności za własny samorząd zawodowy, dbając o kształtowanie nienagannych postaw oraz rozwój zawodowy.

\section{ZASADY SZCZEGÓłOWE:}

\section{Diagnosta laboratoryjny wobec pacjenta}

$\$ 6$

Diagnosta laboratoryjny wykonuje swoje czynności ze świadomością, że wyniki jego pracy chronią zdrowie i życie człowieka.

$\$ 7$

Diagnosta laboratoryjny, stosując całą swoją wiedzę i umiejętności, dąży do uzyskania wiarygodnych wyników badań i dokonuje ich interpretacji dla potrzeb diagnostycznych, leczniczych, sanitarno-epidemiologicznych i profilaktycznych.

$\$ 8$

Diagnosta laboratoryjny postępuje według zasady skuteczności i przydatności diagnostycznej badań.

\section{$\$ 9$}

Diagnosta laboratoryjny z należytą dbałością i starannością pobiera i zabezpiecza pozyskany do badań materiał biologiczny. Materiał pobrany od pacjenta może być za jego zgodą archiwizowany. Diagnosta laboratoryjny zobowiązuje się do jego zabezpieczenia przed użyciem i wykorzystaniem przez osoby trzecie.

\section{$\S 10$}

Diagnosta laboratoryjny wykonujący testy, które służą do identyfikacji nosiciela genu odpowiedzialnego za chorobę, oraz testy, które wykrywają genetyczne predyspozycje 
lub podatność na zachorowanie, może te przeprowadzać wyłącznie dla celów zdrowotnych albo dla badań naukowych związanych z celami zdrowotnymi. Badania te podlegają odpowiedniemu poradnictwu genetycznemu.

\section{Tajemnica zawodowa}

\section{$\$ 11$}

Diagnosta laboratoryjny zobowiązany jest zachować w ścisłej tajemnicy wszystko, czego dowiedzial się o pacjencie podczas przeprowadzanych badań. Zarazem zobowiązany jest on do zabezpieczenia wszelkich w/w informacji przed osobami trzecimi.

\section{$\$ 12$}

Diagnosta laboratoryjny nie może brać udziału w:

1) zatajaniu wyników badań laboratoryjnych,

2) fałszowaniu wyników badań lub nieuzasadnionym zaniechaniu wykonania zleconych badań,

3) popełnianiu plagiatu w pracy naukowej czy dostosowywaniu wyników do postawionej przez siebie lub zleceniodawcę tezy,

4) udostępnianiu wyników badań laboratoryjnych dotyczących pacjenta, bądź też informacji o zagrożeniu dla zdrowia i życia pacjenta każdemu nieuprawnionemu, w tym pracodawcom i firmom ubezpieczeniowym,

5) przekazywaniu materiału biologicznego osobom trzecim,

6) niewłaściwym zabezpieczeniu materiału biologicznego (od pobrania do likwidacji).

\section{$\$ 13$}

Wyniki badań należą do osoby, której one dotyczą, i mogą być tylko przez tę osobę lub za jej zgodą udostępniane innym osobom lub instytucjom.

\section{$\$ 14$}

Diagnosta laboratoryjny, jako przedstawiciel zawodu zaufania publicznego, nie może ujawniać tajemnicy zawodowej, nie może też, w sprawach dotyczących diagnostyki laboratoryjnej, wprowadzać w błąd pacjenta oraz opinii publicznej.

\section{$\$ 15$}

Diagnosta laboratoryjny winien udzielić pacjentowi (na jego wniosek) z najwyższą dokładnością i starannością zrozumiałych informacji o badaniu laboratoryjnym. 


\section{Diagnosta laboratoryjny wobec własnego środowiska}

\section{$\$ 16$}

Biorąc pod uwagę dynamiczny rozwój laboratoryjnej diagnostyki medycznej, diagnosta laboratoryjny powinien:

1) uzupełniać swoją wiedzę poprzez uczestnictwo w konferencjach naukowych i szkoleniach oraz studiowanie piśmiennictwa fachowego,

2) uzyskiwać specjalizacje,

3) czynnie uczestniczyć w inicjatywach swojej korporacji zawodowej zmierzających do doskonalenia organizacji pracy diagnostów laboratoryjnych i rozwoju diagnostyki laboratoryjnej poprzez:

a) współtworzenie standardów jakości medycznych laboratoriów diagnostycznych,

b) poszerzanie zakresu oraz podnoszenie poziomu usług świadczonych przez środowisko diagnostów laboratoryjnych,

c) przestrzeganie zasad dobrej współpracy z osobami wykonującymi inne zawody medyczne,

d) określenie zasad dobrej współpracy między diagnostami laboratoryjnymi ze szczególnym zwróceniem uwagi na eliminowanie problemu nieuczciwej konkurencji,

e) wypracowanie zasad bezpieczeństwa i higieny pracy współwykonujących czynności diagnostyki laboratoryjnej,

f) ustalanie postępowania w dziedzinie ochrony środowiska naturalnego,

g) zabieganie o środki i warunki potrzebne do właściwego wykonywania zawodu,

h) oddziaływanie na finansową i społeczną politykę państwa skierowaną na ochronę zdrowia i życia ludzkiego,

i) współuczestnictwo w procesie przygotowywania programów kształcenia w zakresie diagnostyki laboratoryjnej.

\section{$\$ 17$}

Diagnosta laboratoryjny przestrzega zasady kompetencji, a w wypadku problemów przekraczających jego wiedzę, bądź jakichkolwiek wątpliwości dotyczących uzyskanych wyników lub ich interpretacji winien zasięgać porad odpowiednich specjalistów.

\section{$\$ 18$}

Diagnosta laboratoryjny zobowiązany jest do budowania etosu swojego zawodu, do jego promocji i rozwoju. Szczególnie ważna jest dbałość o budowanie społecznego zaufania, które jest nieodzownym warunkiem dobrego pełnienia zadań ochrony zdrowia. 


\section{$\$ 19$}

Diagnosta laboratoryjny w relacjach $z$ innymi diagnostami laboratoryjnymi w wypadku zauważenia błędów w ich postępowaniu winien $\mathrm{z}$ należnym taktem zwrócić się najpierw do samego zainteresowanego, a w sytuacji szczególnej skonsultować się z jego przełożonym.

\section{$\$ 20$}

Diagnosta laboratoryjny powinien dzielić się swoją wiedzą ze współpracownikami, a sprawując funkcję kierowniczą, nie może utrudniać podwładnym zdobywania wiedzy związanej z wykonywanym zawodem, ma obowiązek motywować ich do rozwoju i ułatwiać podnoszenie kwalifikacji.

\section{Diagnosta laboratoryjny wobec społeczeństwa}

\section{$\$ 21$}

W stosunku do pacjenta, jego rodziny i otoczenia diagnosta laboratoryjny zachowuje należny szacunek oraz przestrzega zasad kultury osobistej.

\section{$\$ 22$}

W stosunku do lekarza zlecającego badania diagnosta laboratoryjny zobowiązany jest do współpracy.

\section{$\$ 23$}

Diagnosta laboratoryjny nie może uzależniać świadczonej przez siebie usługi od dodatkowej gratyfikacji pochodzącej od firm reprezentujących producentów sprzętu i zaopatrzenia medycznego, od samych pacjentów, od firm ubezpieczeniowych, od osób i instytucji w jakikolwiek sposób zainteresowanych uzyskaniem określonych wyników.

\section{$\$ 24$}

W sytuacji zaistnienia konfliktu $\mathrm{z}$ własnym sumieniem diagnosta laboratoryjny może odmówić wzięcia udziału w powierzonych mu czynnościach, jednoznacznie i niezwłocznie o tym informując zainteresowanych oraz swoich przełożonych.

\section{$\$ 25$}

W sytuacji stosowania przez przełożonych lub osoby zlecające badania jakichkolwiek form nacisku, diagnosta laboratoryjny może zwrócić się do swojej korporacji o pomoc i ochronę prawną. 


\section{$\$ 26$}

Diagnosta laboratoryjny w organizacji pracy medycznego laboratorium diagnostycznego i jego kierowaniu postępuje według zasad moralnych, unikając nieuczciwej konkurencji i nepotyzmu.

\section{POSTANOWIENIA KOŃCOWE:}

\section{$\$ 27$}

Niniejszy Kodeks Diagnosty Laboratoryjnego jest zbiorem podstawowych norm etycznych, którymi winien kierować się każdy przedstawiciel zawodu.

\section{$\$ 28$}

Kodeks jest źródłem ogólnych wskazań moralnych, które nie zastępują procesu formacji osobowej i zawodowej diagnosty laboratoryjnego.

\section{$\$ 29$}

Nieustanna refleksja nad sformułowanymi zasadami postępowania diagnosty laboratoryjnego winna stanowić podstawę do doskonalenia postaw moralnych i zawodowych diagnostów laboratoryjnych.

\section{$\$ 30$}

Dbałość o przestrzeganie i egzekwowanie zasad Kodeksu Etyki Diagnosty Laboratoryjnego przez diagnostę laboratoryjnego spoczywa na władzach Korporacji, a w szczególności na członkach Komisji ds. Etyki.

\section{Słownik podstawowych pojęć użytych w Kodeksie:}

1. Cnota; stała dyspozycja człowieka do czynienia dobra, czyli stała gotowość człowieka do postępowania moralnego. Podstawowe cnoty to: dobroć, męstwo, umiarkowanie, sprawiedliwość.

2. Ekonomika; umiejętność osiągania maksymalnego rezultatu przy zastosowaniu optymalnych środków, czyli sposób racjonalnego zarządzania środkami dla uzyskania oczekiwanego rezultatu. Często ekonomikę kojarzy się z oszczędnym zarządzaniem dobrami.

3. Etos; zwyczaj postępowania przyjęty przez określoną społeczność. Zbiór nienaruszalnych zasad moralnych, czyli pewien wzorzec godziwego postępowania człowieka. Często przez etos rozumie się zbiór wartości szczególnie cenionych w danej społeczności np. etos rycerski, etos zawodowy, etos wynikający z religijnego wychowania np. chrześcijański, muzułmański, judaistyczny. Innym jest np. etos lekarski, etos prawniczy, etos urzędniczy etc, wynikający z pragmatyki postępowania danej grupy społecznej czy zawodowej. 
4. Etyka; dziedzina filozofii, która w oparciu o umyst/o rozum/o naturalne zdolności poznawcze czlowieka ustala normy postępowania, to znaczy określa się, jakie postępowanie, jakie działanie prowadzić mogą do osiągnięcia szczęścia i realizować będą dobro człowieka. \ym zajmuje się etyka normatywna. Zaś etyka opisowa opisuje i analizuje postępowanie człowieka nie tworząc normatywu powinnościowego, podobnie jak etyka sytuacyjna, relatywistyczna.

5. Formacja osobowa; wzór osobowy realizowany w procesie wychowania poprzez naśladownictwo i odwzorowanie pożądanych postaw moralnych w społeczeństwie. Zespół działań zmierzających do kształtowania pożądanej postawy moralnej człowieka. Formacja osobowościowa realizowana jest w procesie wychowania na dyspozycjach genetycznych. Ogromną rolę w procesie formacji osobowej stanowią autorytety, czyli osobowe wzorce postępowania.

6. Formacja zawodowa; kształtowanie i doskonalenie umiejętności zawodowych człowieka. Obejmuje ona zarówno kształtowanie zdolności technicznych, jak i dojrzałości osobowej, co ma szczególne znaczenie w przypadku zawodów zaufania publicznego. \worzenie wzoru osobowego w danym zawodzie.

7. Godność; jedna z wartości, której człowiek doświadcza, jej pragnie i ma prawo jej bronić. Zbiór najbardziej wartościowych cech człowieka decydujących o jego wyjątkowości i niepowtarzalności. Godność rozpoznawana jest często jako naczelna wartość, której naruszenie dotyka czegoś najistotniejszego w strukturze osoby ludzkiej.

8. Kodeks etyczny; zbiór norm postępowania moralnego przyjęty przez grupę osób, na przykład przez korporację zawodową. Sankcją wynikającą z niestosowania się do kodeksu jest sytuowanie się poza grupą określającą w kodeksie standardy postępowania. Kodeks jest jednym $\mathrm{z}$ ważnych instrumentów formacji zawodowej, która ma szczególne znaczenie w odniesieniu do zawodów zaufania publicznego.

9. Komisja etyczna; wybrany przez przedstawicieli grupy społecznej cieszący się szacunkiem wielu osób zespół, któremu powierza się troskę o respektowanie zasad moralnych, także ocenę postępowania członków wybranej wspólnoty, czyli jest to zespół wybranych osób spełniający nadzór nad respektowaniem norm deontycznych, w którego kompetencji leży ocena czynów poddanych osądowi i wartościowaniu ze względu na okoliczności tego czynu. Komisja etyczna spełnia rolę opiniotwórczą wobec czynów zgłoszonych do oceny.

10. Norma deontyczna; przyjęty i nakazany przez określoną grupę osób sposób postępowania tak wobec własnych członków, jak również wobec członków innych społeczności. Podstawową normą deontyczną jest nakaz czynienia dobra i unikania zła.

11. Deontologia; - nauka o nakazach i zakazach moralnych. W systemach etycznych, w których niemożliwe jest racjonalne ustalenie norm moralnych deontologia staje się jedynym sposobem oceny czynów ludzkich, które odnosi się do 
zakazów i nakazów. Kodeks etyczny ma charakter deontologiczny, choć winien opierać się na podstawowych normach etycznych.

12. Nepotyzm; kierowanie się przy podejmowaniu decyzji o wymiarze społecznym interesem osób najbliższych ( np. rodziny); czyli - wykorzystywanie swojej funkcji i stanowiska do obsady członkami rodziny określonych funkcji, lukratywne stanowiska lub czynienie $z$ nich dysponentów władzy.

13. Normy moralne; ogólne zasady postępowania chroniące dobro człowieka.

14. Osoba; jednostka ludzka rozumna, zdolna do poznania i wolnego wyboru. Dzięki zdolności poznania i wolnego wyboru działania osoby ludzkiej są świadome, odpowiedzialne i mają wymiar moralny. Podstawowymi własnościami charakteryzującymi człowieka jako osoby są godność, jedyność i niepowtarzalność. Wynikają one $z$ rozumnej natury człowieka, który zdolny jest poznawać, oceniać i w sposób wolny wybierać. Dzięki temu czyny ludzkie są wolne, i niosą z sobą odpowiedzialność.

15. Prawo naturalne; zbiór podstawowych norm moralnych rozpoznawalnych na poziomie naturalnych zdolności poznawczych człowieka, czyli w sposób rozumny są rozpoznane zasady godziwego postępowania. Podstawowe zasady prawa naturalnego każą chronić życie, zdrowie i nienaruszalność godności osoby ludzkiej. Prawo stanowione winno wynikać i odnosić się do podstawowych zasad prawa naturalnego.

16. Sumienie; świadomość moralna osoby ludzkiej w momencie dokonywania wyboru (podejmowania decyzji), czyli wewnętrzne przekonanie informujące o godziwości bądź niegodziwości czynu.

17. Wartość; podstawowa kategoria etyczna oznaczająca wszystko, co rozpoznawane jest przez człowieka jako cenne i godne pożądania. Wartość rozumiana jest jako pewien wzór i cel działań moralnych człowieka a zarazem narzędzie oceny moralnej czynów ludzkich.

18. Zasada moralna; reguła, którą winien się posługiwać człowiek w ocenie własnych wyborów, własnego postępowania. (odp. na pytanie: czym się kierowałeś?). 


\section{The Code of Ethics of a Laboratory Diagnostician}

\section{SUMMARY}

The need to establish the Code of Ethics of a Laboratory Diagnostician stems from the development of medicine in which the specialized laboratory diagnostics has been playing an increasingly important role. Not only does it help determine accurate diagnostics which enables effective therapy, but also contributes to the development of wider health service and preventive medicine. It is thus understandable that with the service providers and patients becoming increasingly aware of the importance of laboratory diagnostics, it has gained the status of the profession of public trust. In practice, it means that laboratory diagnosticians set themselves high moral and professional standards. The Code of Ethics of a Laboratory Diagnostician, the signatories of which are individual laboratory diagnosticians through their representatives who attended the Extraordinary National Meeting of Laboratory Diagnosticians on January 13, 2006, will be very important in education of specialists. The Code expresses the moral awareness of the laboratory diagnostics community, and also provides the basis for assessment of professional involvement and moral stance of the members of the Corporation.

The Code of Ethics of a Laboratory Diagnostician is grounded in generally accepted ethical standards as well as the principles originating from the professional tradition. The principal standard of conduct of a laboratory diagnostician involves consideration of the welfare of a human being, which should be protected both in the individual and social context. This principle provides for the obligation to respect human dignity and establishes reference for professional practice so that its primary objective would cover service to a patient in accordance with commonly respected values such as honesty, reliability and competency.

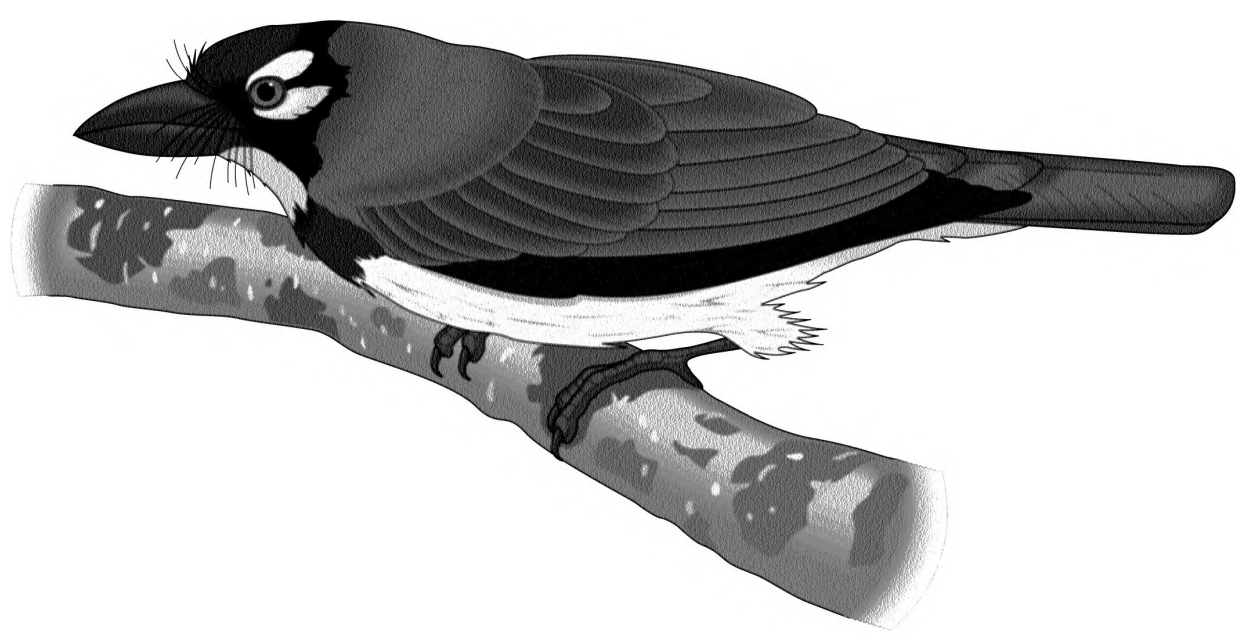

